\title{
PENGELOLAAN AGENDA PERUBAHAN IKLIM \\ DALAM SKENARIO SISTEM DUNIA KAPPEN: RESPONS KEBIJAKAN INDONESIA
}

\author{
Global Climate Change Management in The Kappenis' World System Scenario: \\ Indonesia's Policy Response
}

Hariyadi

\author{
Peneliti Madya Bidang Ekonomi dan Kebijakan Publik \\ Pada Pusat Penelitian Badan Keahlian DPR RI \\ Alamatemail: hariyadi@dpr.go.id
}

Naskah Diterima: 4 Agustus 2017

Naskah Direvisi: 22 November 2017

Naskah Diterima: 22 November 2017

\begin{abstract}
Climate change issue will continue to become a crucial one both in national and international arena. Nowdays, efforts to manage this issue may be seen in the framework of a world system scenario that may arise and that each state may respond the issue appropriately. By using Kappen's world system scenario, management of national and global climate change issue still confronts a serious challenge. This article concludes that each state shall take a satisfycing policy. Thus, Indonesia should place its policy frameworks in the network and fragmented world system scenarios. Under these scenarios, Indonesia's policy shall strengthen the global climate management that is based on the principles such as the common but differentiated responsibility, climate justice, and the rights to development. To achieve this, through a constructive engagement diplomacy, Indonesia needs to take some effortsto achieve its global climate commitment nationally as modalities to push developed nations' climate commitment.
\end{abstract}

Keywords: climate change, world system, global governance, policy response

\begin{abstract}
Abstrak
Isu perubahan iklim telah menjadi isu penting dalam konstelasi politik nasional dan global. Secara kekinian, upaya untuk mengelola isu tersebut dapat dilihat dengan sebuah skenario sistem dunia yang akan terjadi sehingga setiap negara dapat meresponsnya secara tepat. Dengan menggunakan skenario sistem dunia yang digagas van Kappen pengelolaan isu perubahan iklim secara nasional dan global masih menghadapi tantangan berat. Kajian ini menyimpulkan bahwa setiap negara harus mengambil kebijakan satisfycing. Dalam konteks ini, Indonesia harus lebih mendasarkan kebijakannya dalam skenario sistem dunia terfragmentasi van Kappen. Dalam konstelasi skenario sistem ini, kebijakan Indonesia harus mendorong upaya pengelolaan perubahan iklim berdasarkan prinsip-prinsip common but differentiated responsibilities, keadilan iklim, dan hak membangun. Untuk mewujudkan kebijakan ini, melalui diplomasi konstruktif Indonesia perlu berupaya mewujudkan komitmen penurunan emisinya secara nasional dalam rangka mendorong komitmen negaranegara maju.
\end{abstract}

Kata kunci: perubahan iklim, sistem dunia, global governance, respons kebijakan

PENDAHULUAN

\section{Latar Belakang}

Upaya untuk menangani isu perubahan iklim secara global (global governance) masih akan menghadapi tantangan berat. Beratnya tantangan ini tentu diakibatkan oleh kompleksitas struktur konstelasi politik global yang polarisasinya tidak bisa dibedakan secara jelas. Selain itu, sejumlah faktor juga berperan terhadap tantangan ini seperti menurunnya peran tradisional negara dalam artian riil, 
turunnya peran 'hegemonik' negara-negara yang selama ini berperan penting, dan meningkatnya peran aktor non-negara. ${ }^{1}$ Beratnya tantangan ini juga bisa dilihat dari besarnya tingkat kenaikan emisi gas rumah kaca (GRK) secara global. Sampai tahun 2014, emisi tersebut telah mencapai 49 gigaton setara karbon $\left(\mathrm{GtCO}^{2} \mathrm{e}\right)$. Dalam kurun waktu 2000-2010, seiring dengan tingkat pertumbuhan ekonomi, perkembangan teknologi, gaya hidup, dan pertumbuhan penduduk, tingkat emisi ini mengalami kenaikan terbesar dalam sejarah, dibandingkan dengan tiga dekade sebelumnya (1970-2000). Dalam kurun waktu 2000-2010 misalnya, emisi GRK mengalami kenaikan rata-rata sebesar 1 $\mathrm{GtCO}^{2} \mathrm{e}(2,2 \%) /$ tahun dibandingkan dengan kenaikan rata-rata sebesar $0,4 \mathrm{GtCO}^{2} \mathrm{e}(1,3 \%) /$ tahun dalam kurun waktu 1970-2000.2

Sektor energi memberikan kontribusi yang sangat signifikan terhadap kenaikan tingkat emisi tersebut. Data menunjukkan bahwa emisi GRK dari pembakaran energi fosil dan industri telah menyumbang kira-kira $78 \%$ dari tingkat emisi global secara total selama kurun waktu 1970-2010. Sampai tahun 2010, tingkat emisi ini mencapai $32 \mathrm{GtCO}^{2} \mathrm{e} / \mathrm{tahun}$, mengalami kenaikan 3\% pada 2010-2011, dan mencapai 1-2\% pada periode 2011-2012. Pada tahun 2010, dari $49 \mathrm{GtCO}^{2} \mathrm{e} /$ tahun tingkat emisi GRK antropogenik, $\mathrm{CO}^{2}$ tetap menjadi emiter utama mencapai $76 \%$ atau lebih dari dua per tiga tingkat emisi GRK global. ${ }^{3}$

Thomas G. Weiss and Ramesh Thakur. Global Governance and the UN, an Unfinished Journey (Bloomington and Indianapolis: Indiana Univ. Press, 2010). Thomas G. Weiss, Governance, Good Governance and Global Governance: Conceptual and Actual Challenges, dalam Ashwani Kumar dan Dirk Messner (ed.). Power Shifts and Global Governance, Challenges from South and North (UK \& USA: Anthem Press, 2011), 68-88.

Edenhofer, O., R. Pichs-Madruga, Y. Sokona, E. Farahani, S. Kadner, K. Seyboth, A. Adler, I. Baum, S. Brunner, P. Eickemeier, B. Kriemann, J. Savolainen, S. Schlömer, C. von Stechow, T. Zwickel and J. C. Minx, eds. Climate Change 2014: Mitigation of Climate Change. Contribution of Working Group III to the Fifth Assessment Report of the Intergovernmental Panel on Climate Change. (UK and NY, USA: Cambridge University Press, 2014).

Edenhofer et al.Cimate Change 2014.
Secara global, pertumbuhan penduduk dan kegiatan ekonomi terus menjadi pendorong utama peningkatan emisi GRK. Kontribusi kegiatan ekonomi bahkan telah mengalami kenaikan tajam. Antara tahun 2000 dan 2010, kontribusi kedua sektor ini bahkan melebihi tingkat pengurangan emisi yang diakibatkan oleh upaya peningkatan intensitas energi. Oleh karena itu, tanpa upaya keras, kedua sektor tersebut akan mendorong tingkat kenaikan emisi global yang jika tanpa intervensi (business as usual) dapat berakibat pada naiknya temperatur global rata-rata mencapai $3,7{ }^{\circ} \mathrm{C}$ atau $4.8^{\circ} \mathrm{C}$ dibandingkan dengan tingkat praindustri. ${ }^{4}$

Dengan demikian, pengelolaan isu perubahan iklim akan tetap berpotensi menjadi isu pertarungan politik dan kepentingan antarnegara, khususnya negara-negara maju. ${ }^{5}$ Potensi ini tentu terkait dengan skenario konstelasi sistem politik internasional yang tidak dapat dipetakan secara pasti. Secara nasional kondisi seperti ini akan turut mempengaruhi bagaimana setiap negara harus merespons di tengahtengah beratnya tantangan pembangunan nasional mereka masing-masing. Untuk sebagian, konstelasi seperti ini akan mendorong negara-negara berkembang untuk memperkuat penerapan prinsip 'hak membangun' (rights to development) dan prinsip tanggung jawab bersama tetapi dibedakan (common but differentiated responsibility). Hal ini terjadi tentu seiring dengan semakin kuatnya tekanan negara-negara maju terhadap negara-negara berkembang untuk turut mengambil bagian (burden-sharing) dalam isu perubahan iklim. Sebagai salah satu negara berkembang yang telah mengikatkan diri secara politik dan legal dalam isu perubahan iklim, Indonesia tidak terlepas dari persoalan ini.

Konstelasi sistem politik internasional dapat didekati ke dalam beberapa skenario. Frank van

\footnotetext{
Varun Sivaram and Teryn Norris,"The Clean Energy Revolution: Fighting Climate Change With Innovation". Foreign Affairs, Vol. 95, Issue 3, (June 2016): 147-156. Richard Little. The Balance of Power in International Relations: Metaphors, Myths and Models (UK: Cambridge Univ. Press, 2007).
} 
Kappen misalnya, telah mengkonsepsikannya ke dalam empat skenario kuadran yang di dalamnya setiap skenario akan mendorong kebijakan yang berbeda-beda bagi setiap negara dalam menyikapi isu-isu global. Dalam setiap kuadran tersebut, sejumlah variabel yang melekat di dalamnya turut memberikan warna terhadap setiap skenario, yakni potensi kerja sama, kecenderungan lemahnya kerja sama, dan aktor-aktor yang terlibat di dalamnya, baik aktor negara dan non-negara. Skenario ini terlihat sejalan dengan pendekatan realisme dan idealisme klasik.

Pendekatan realisme klasik mengasumsikan bahwa setiap negara memiliki kepentingan yang berbeda-beda dan dapat mengarah pada konflik. Asumsi realisme juga meyakini bahwa kekuatan suatu negara itu menentukan hasil dari konflik dan pengaruh satu negara terhadap negara lain. Selain itu, realisme politik klasik memandang bahwa politik ditujukan meningkatkan kekuasaan. ${ }^{6}$ Pendekatan ini kemudian dikembangkan ke dalam paham neorealisme baru yang lebih memfokuskan pada 'struktur' sistem internasional yang sifatnya anarkhis dan konsekuensinya bagi hubungan antar-negara, serta kecenderungan setiap negara kecil untuk beraliansi dengan kekuatan besar untuk menjaga otonominya. ${ }^{7}$ Sementara itu, pendekatan idealisme klasik merujuk pada alternatif pendekatan dan metode untuk merubah konstelasi sistem politik internasional yang didasarkan pada nilai-nilai baik dari sifat dan perilaku manusia. Dengan demikian, paham idealisme mendorong penguatan kerja sama internasional dan penyebaran nilai-nilai moral dan hukum internasional. ${ }^{8}$

\section{Perumusan Masalah}

Disahkannya Paris Agreement

.--instrumen yang untuk pertama kalinya dapat menyatukan semua negara---dan implikasinya

John T. Rourke. International Politics on the World Stage (California: Brooks/Cole Publishing Co., 1986).

Robert Jackson \& George Sorensen. Pengantar Studi Hubungan Internasional, (terj.) (Yogyakarta: Pustaka Pelajar, 2005).

8 Rourke, International Politics on. bagi upaya terbaik melalui skema Nationally Determined Contributions (NDC) dalam Konferensi PBB tentang Perubahan Iklim (COP-22) tahun 2016 di Maroko, menawarkan sebuah konstelasi politik internasional yang kondusif dalam pengelolaan isu perubahan iklim. Akibatnya, ratifikasi Indonesia terhadap PA dapat dipandang sebagai opsi terbaik untuk memperkokoh komitmen nasional dan memerangi perubahan iklim global. ${ }^{9}$

Namun demikian, sejumlah kebijakan AS yang menarik diri dari sejumlah kesepakatan rezim persetujuan internasional, seperti kerja sama kemitraan trans-pasifik (TPP) dan, baru-baru ini, PA, menunjukkan rapuhnya kondusifitas sistem dunia bagi pengelolaan isu ini. Dalam konteks inilah, kajian ini akan melihat bagaimana arah konstelasi politik global ke depan dalam skenario sistem politik internasional Frank van Kappen dan dampaknya terhadap upaya penanganan agenda perubahan iklim. Secara nasional isu ini sekaligus juga akan menentukan bagaimana Indonesia harus menyikapinya.

\section{Tujuan Penulisan}

Penulisan kajian ini ditujukan untuk memperkaya diskursus akademik pengelolaan isu perubahan iklim nasional dalam rangka merespons upaya global dalam konsteks skenario sistem dunia Kappen. Hasil diskursus ini diharapkan dapat memberikan pemikiran bagi para pengambil kebijakan dalam merespons isu ini dalam upaya memenuhi komitmen penurunan emisi GRK sebesar 29\% dengan dana sendiri dan 41\% dengan dukungan asing, meratifikasi PA, dan serangkaian kebijakan lainnya.

\footnotetext{
United Nations Framework Convention on Climate Change/UNFCCC. "The Paris Agreement", UNFCCC, diakses kembali 19 Juni 2017, http://unfccc.int/paris_ agreement/items/9485.php,. Kementerian Lingkungan Hidup dan Kehutanan (KLHK). "Indonesia Ajak Negara Sahabat Bekerjasama Tunaikan Persetujuan Paris", KLHK, diakses 14 November 2016, http://www.fordamof.org/berita/post/3177.
} 


\section{Gambar 1. Skenario Sistem Dunia Kappen}

WORLD SCENARIO

STATES

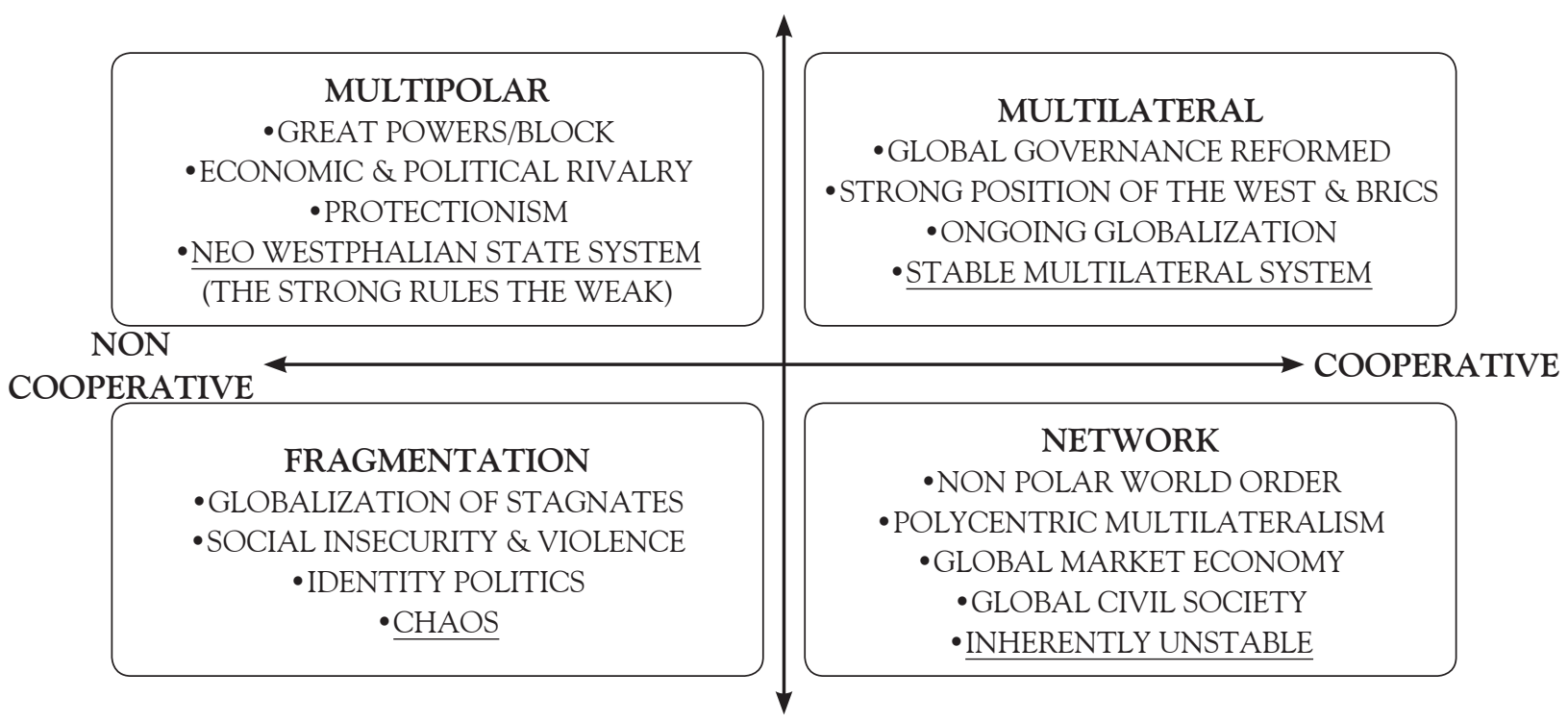

VARIOUS ACTORS

\& NON STATE ACTORS

Sumber: Kappen, tt.

\section{Kerangka Pemikiran}

\section{Skenario Kuadran Sistem Dunia Kappen}

Menurunnya komitmen sejumlah negara di tingkat kawasan dan global dewasa ini dalam isu perubahan iklim memberikan tantangan tersendiri bagi semua negara dan sekaligus menjadi bahan untuk meredifinisi konsepsi kepentingan nasional mereka. Dalam konteks ini, konstelasi politik internasional akan semakin dipenuhi dengan ketidakpastian. Kondisi ini diperburuk dengan semakin kuatnya aktor non-negara dan semakin turunnya peran tradisional negara-bangsa. Akibatnya, proses tata kelola sistem politik internasional akan semakin sulit dilakukan.

Frank van Kappen telah mengkonsepsikan sistem internasional ke depan ke dalam empat skenario kuadran yang di dalamnya setiap skenario memberikan tantangan tersendiri dalam pengelolaan isu-isu global (global governance). Dalam setiap kuadran tersebut, sejumlah variabel yang melekat di dalamnya turut memberikan warna terhadap setiap skenario, yakni potensi kerja sama, kecenderungan lemahnya kerja sama, dan aktor-aktor yang terlibat di dalamnya, baik aktor negara dan non-negara. Keempat skenario itu dapat disarikan berikut ini. ${ }^{10}$

Pertama, skenario Kuadran I adalah terciptanya sistem global yang sifatnya multipolar (Neo-Sistem Negara Westphalian). Skenario ini dicirikan dengan kuatnya peran negara, meskipun tidak sekuat peran negara dalam artian sistem negara-bangsa Westphalian. Namun demikian, potensi kecenderungan lemahnya kerja sama juga mencirikan skenario ini. Lebih lanjut, beberapa faktor penting mencirikan skenario ini adalah munculnya blok negaranegara besar, kecenderungan proteksionisme, kuatnya persaingan politik dan ekonomi, kecenderungan berlakunya sistem sistem negarabangsa neo-Westphalian di mana negara-negara kuat menguasai negara-negara lemah. Era Perang Dingin sedikit mencirikan hal ini meskipun dalam masa ini kekuatan dua kutub lebih dominan secara diametral. Dengan menggunakan paham realisme politik, percaturan politik internasional digambarkan sebagai sistem yang 'anarkhis' sehingga setiap negara dapat melakukan upaya

\footnotetext{
10 Frank van Kappen. "New security threats; The UN, NATO and Challenges in global governance", Clingendael Lecture (tanpa tahun).
} 
politik melalui perebutan pengaruh untuk memenuhi kepentingan nasional baik melalui pola keseimbangan kekuatan (balance of power) maupun keseimbangan teror (balance of terror) atau melalui pendekatan idealisme politik di mana kepentingan setiap negara dapat direkonsiliasikan melalui kelembagaan rezim atau organisasi internasional yang mengikat semua pihak. ${ }^{11}$

Kedua, skenario Kuadran II adalah terjadinya sistem global bersifat multilateral (Sistem Multilateral Homogen). Skenario ini dicirikan dengan potensi kuatnya kerja sama antar-negara. Potensi kuatnya kerja sama ini karena dalam kerangka sistem ini, sistem multilateral dapat dikelola secara stabil, proses globalisasi terus berjalan dan adanya reformasi tata kelola isu-isu global. Era pasca-Perang Dingin sedikit banyak merefleksikan hal ini. Dengan menggunakan paham idealisme politik, percaturan politik internasional dalam skenario ini dapat menjadi arena yang kondusif bagi terciptanya pelembagaan kerja sama melalui lembaga-lembaga yang dibentuk bersama dalam rangka merekonsiliasikan setiap pertarungan kepentingan sehingga setiap negara dapat mengoptimalkan pencapaian kepentingan nasionalnya masing-masing. ${ }^{12}$ Namun demikian, skenario sistem ini sedikit banyak juga mencirikan adanya potensi ketidakadilan di dalam negara dan/atau antar-negara, atau yang menurut teori ketergantungan Johan Galtung, misalnya (lebih dikenal sebagai teori imperialisme struktural) ${ }^{13}$ sebagai hubungan yang tidak seimbang karena skenario ini mengindikasikan terjadinya penguatan posisi politik negara-negara maju dan negara-negara yang memiliki kapasitas skala ekonomi dan penduduknya besar seperti yang tergabung dalam kelompok BRICS (Brazil, Rusia, India, Cina, dan Afrika Selatan).

11 Hans J. Morgenthau, Politik Antar-Bangsa (terj.). Direvisi Kenneth W Thompson. (Jakarta: Yayasan Pustaka Obor Indonesia, 2010).

12 Morgenthau, Politik Antar-Bangsa.

13 Johan Galtung, "A Structural Theory of Imperalism", Journal of Peace Research, Vo. 8, No. 2, (1971): 81-117. Donald Light et al. Sociology. Fifth ed. (New York: Alfred A . Knopf, Inc., 1989).
Ketiga, skenario Kuadran III adalah terjadinya sistem global yang bersifat jaringan (multilateralisme polisentris). Sama seperti skenario Kuadaran II, skenario ini dicirikan dengan potensi kuatnya kerja sama antarnegara atau dengan aktor-aktor non-negara. Potensi kuatnya kerja sama ini karena sistem multilateral tidak menyatu, kuatnya aktor-aktor sipil global dan berlakunya sistem ekonomi pasar. Era sekarang ini dalam batas tertentu mencerminkan skenario ini. ${ }^{14}$ Skenario ini juga sekaligus menguatkan pola tata kelola isu-isu global yang sifatnya semakin partisipatoris dan semakin kuatnya peran aktor non-negara dan kekuatan sipil khususnya entitas bisnis. ${ }^{15}$ Selain itu, hal yang mencirikan skenario ini bahwa sifat kerja samanya biasanya bersifat fungsional/ ekonomi. Namun demikian, seiring dengan turunnya peran negara secara tradisional dan semakin kuatnya peran aktor-aktor nonnegara, potensi instabilitas konstelasi sistem dunia pun tidak terhindarkan. Dalam batas tertentu, politisasi isu-isu ketidakadilan sosial dan ekonomi secara global, biasanya mendorong terjadinya instabilitas tersebut. Kritik Stiglitz terhadap dampak negatif globalisasi misalnya, untuk sebagian merefleksikan hal ini. ${ }^{16}$

Keempat, skenario Kuadran IV adalah terciptanya sistem global yang sifatnya terfragmentasi (Fragmented New World Order). Sistem ini merefleksikan sebuah konstelasi politik internasional yang kurang kondusif. Sistem ini mencirikan beberapa hal, misalnya, adanya potensi anarkhisme politik, sosial ekonomi dalam skala global. Selain itu, ciri yang lain mencakup kuatnya politik identitas. Karena sifat sistem ini tidak mendorong adanya trustsehingga pada akhirnya kerja sama pun sulit dilakukan. Situasi seperti ini tentu diakibatkan oleh lemahnya peran negara sehingga dapat berakibat pada situasi chaotic. Sama seperti skenario Kuadran I (multipolar), dengan menggunakan paham realisme politik, percaturan politik internasional digambarkan

\footnotetext{
Weiss, "Governance, Good Governance...".

Weiss, "Governance, Good Governance...".

Stiglitz, Joseph E. Globalization and Its Discontents (New York: Norton, 2002).
} 
sebagai sistem yang 'anarkhis'. Bedanya, dalam skenario kuadran keempat ini, peran negara secara tradisional sebagai sebuah entitas hukum sifatnya tidak sekuat pada skenario multipolar.

Kappen mengidentifikasi sejumlah faktor yang mendorong terjadinya ketidakpastian tersebut antara lain, persoalan ketimpangan antara pertumbuhan demografis dengan lapangan kerja, perubahan iklim, keterbatasan sumber daya seperti energi, air dan barang-barang mentah, menguatnya fundamentalisme dan irasionalisme, melemahnya sistem negara-bangsa dan lembagalembaga dunia, perubahan kekuatan dunia secara horisontal dan vertikal, serta terjadinya proliferasi senjata pemusnah massal.

Dalam kondisi demikian, lingkungan keamanan berada dalam kondisi penuh ketidakpastian. Dalam situasi seperti itu, setiap negara akan dihadapkan pada situasi di mana setiap negara tidak tahu kapan, di mana, mengapa dan dengan siapa konflik akan terjadi. Dalam skenario seperti ini, eksistensi setiap negara akan diposisikan sama seperti adagium teori Darwin bahwa eksistensi sebuah spesies tidak ditentukan oleh kuat lemahnya tetapi mereka yang paling dapat beradaptasi dengan lingkungan yang selalu berubah. ${ }^{17}$

Menurut pandangan inisejumlah ancaman yang dapat muncul dalam waktu dekat antara lain, bauran ancaman pertahanan dan keamanan yang sangat sulit diperkirakan,perang geopolitik antar-negara, perangsipil di wilayahwilayah yang tidak dapat dikelola secara penuh oleh pemerintah yang berwenang, serangan yang sama sekali tidak diperkirakan sebelumnya oleh negara tertentu dan aktor-aktor nonnegaradengan menggunakan kemajuan teknologi, potensi terjadinya perang hibrid, dan semakin kuatnya potensi perang di lautan atau wilayah pantai. ${ }^{18}$

\section{Konsepsi Global Governance}

Konsepsi sistem internasional juga dapat dinilai dengan cara pandang bagaimana global governance (tata kelola global) seharusnya dilakukan.Global governance dapat diartikan sebagai proses atau

\footnotetext{
$17 \quad$ Kappen, "New security threats...", Clingendael Lecture.
} 18 Ibid. sekumpulan cara yang dipakai setiap individu atau lembaga, baik publik maupun swasta, untuk mengatasi masalah global bersama. Proses ini berlangsung secara berkesinambungan sehingga konflikdanserangkaian perbedaandirekonsiliasikan melalui kerja sama. Secara kelembagaan, proses ini melibatkan lembaga-lembaga formal untuk menegakkan kesepakatan formal dan informal bagi setiap pihak yang telah menyetujui atau mempersepsikannya sebagai kepentingannya. Secara politis, tata kelola global ini identik dengan hubungan antar-pemerintah meskipun kini ia juga melibatkan organisasi non-pemerintah, gerakan sosial, perusahaan multinasional, pasar modal global, dan media massa.

Selain itu, seiring dengan tidak adanya kekuatan tunggal yang secara absolut dapat menguasai semua dalam rangka tata kelola global (primus interpares), peran salah satu pihak yang memiliki posisi dominan secara politik dan ekonomi hanya berfungsi sebagai penggerak utama proses ini. Mekanisme inilah yang dikonsepsikan dengan istilah polisentrisme. ${ }^{19}$ Dengan cara pandang ini, melalui kerja sama internasional, tata kelola global diasumsikan akan mampu menjadi mekanisme yang efektif bagi setiap aktor yang terlibat di dalamnya. Situasi ini pada akhirnya akan mendorong terjadinya proses pendalaman, perluasan dan penguatan keterhubungan secara transnasional baik formal maupun non-formal dalam dimensi sosial-ekonomi dan politik. ${ }^{20}$

Kini, proses globalisasi ekonomi dan politik telah mengarah pada situasi di mana sistem negara-bangsa menjadikan negara yang pada awalnya sebagai satu-satunya aktor penting dalam pengambilan keputusan kini tidak lagi relevan dalam pengertian absolut. Dengan demikian, proses tata kelola tersebut akan semakin inklusif. Dengan kata lain, organisasi internasional akan bekerja sama secara erat dengan aktor-aktor non-negara dalam proses itu. Untuk mencapai tujuan ini, peran satu atau beberapa negara tertentu sebagai motor penggerak utama proses initetap penting.

\footnotetext{
19 Weiss and Thakur, Global Governance. Weiss, "Governance, Good Governance...".

20 Weiss, "Governance, Good Governance...".
} 
Untuk mencapai tujuan ini, prosesnya tidak saja mensyaratkan adanya demokratisasi organisasi internasional tetapi juga perubahan arena bermain secara global. ${ }^{21}$ Stiglitz menggunakan istilah dunia yang tidak lagi ideologis.

\section{PEMBAHASAN}

\section{Pengelolaan Isu Perubahan Iklim Global}

Panel antar-Pemerintah untuk Perubahan Iklim (IPCC) mengartikan perubahan iklim sebagai perubahan keadaan iklim yang dapat diidentifikasi, antara lain, melalui uji statistik, atau dengan perubahan-perubahan rata-rata atau variabilitas setiap komponen yang ada, dan yang berlangsung dalam jangka panjang, biasanya dalam beberapa dekade atau lebih. ${ }^{22}$ Sementara itu, Konvensi Kerangka Kerja PBB untuk Perubahan Iklim (UNFCCC) mengartikan perubahan iklim sebagai perubahan keadaan iklim yang diakibatkan secara langsung maupun tidak langsung oleh aktivitas manusia yang terbukti telah merubah komposisi atmosfir global dan perubahan iklim yang terjadi secara alamiah dalam kurun waktu yang dapat disandingkan secara komparatif.. ${ }^{23}$ Dari definisi ini dapat ditegaskan bahwa perubahan iklim global sebenarnya menjadi sebuah fenomena alamiah karena dipicu oleh perubahan keseimbangan pemanasan bumi.

Sejak era industri, emisi GRK akibat aktivitas manusia telah menjadi faktor utama perubahan iklim secara global. Akibatnya, laju kontribusi emisi antropogenik khususnya dari sumber pembakaran energi fosil dan industri dan diindikasikan dengan konsentrasi GRK di atmosfir bumi, justru telah mencapai pada tingkat yang sangat signifikan secara global (Gambar 2). ${ }^{24}$

Gambar 2. Emisi CO² dari Sumber Energi Fosil dan Industri 1970-2015

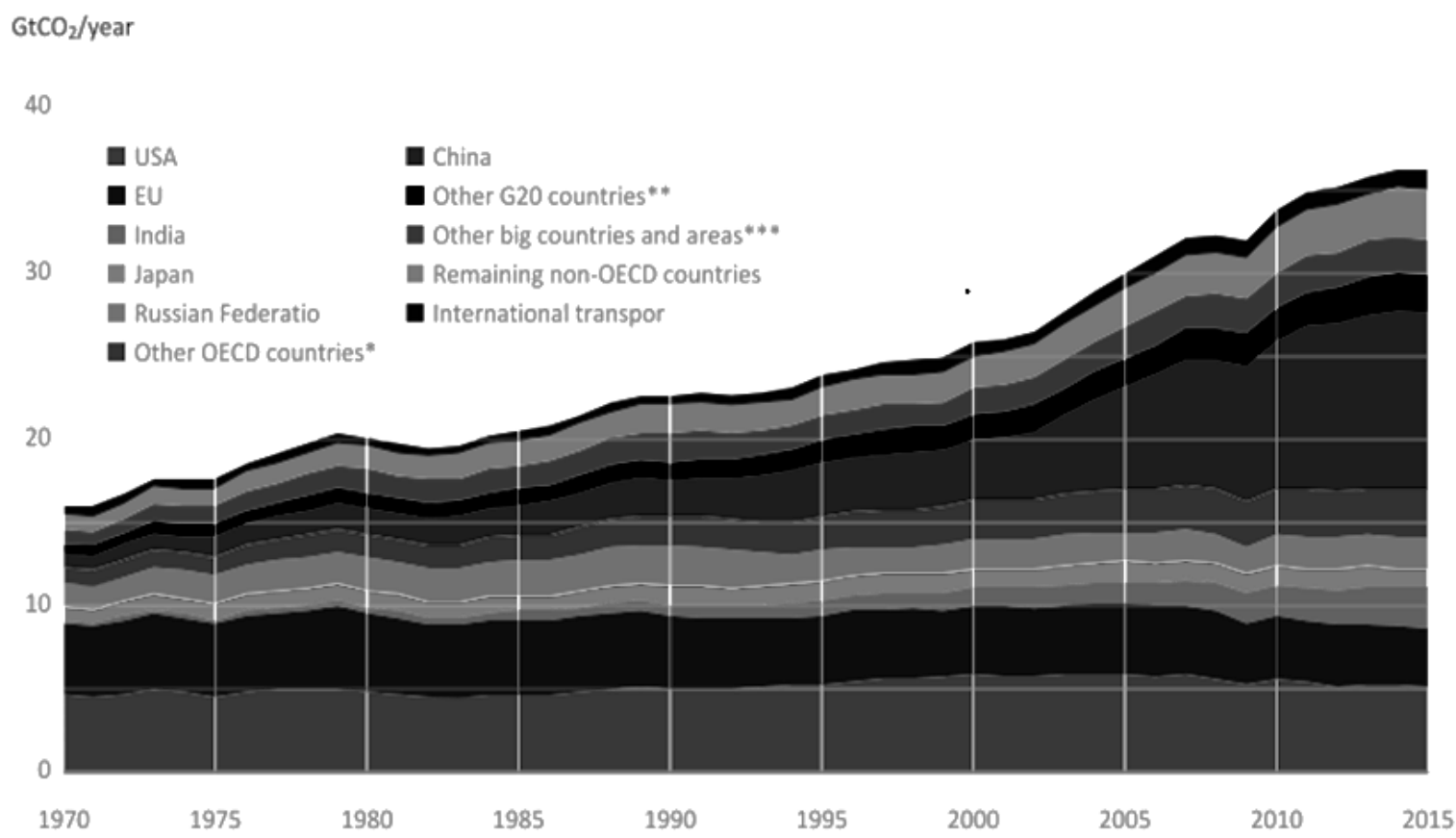

- Other OECD countries include Australia; Canada; Mexico; Republic of Korea and Turkey.

** Other G20 countries include Argentina; B azil; Indonesia; Saudi Arabia; South Africa and Turkey.

*** Other big countries and areas include Egypt; Iran; Kazakhstan; Malaysia; Nigeria; Taiwan, Province of China; Thailand and Ukraine.

Sumber: UNEP, 2017.

21 Weiss, "Governance, Good Governance...".

22 Inter-Governmental Panel on Climate Change/IPCC. "Climate Change 2007: Mitigation of Climate Change". Contribution of Working Group III to the Fourth Assessment report of the IPCC. Summary for Policy Makers and Technical Summary, 2007.
IPCC, "Climate Change 2007".

4 Sutamihardja dan Mari Eko Mulyani. "Climate Change, Dokumen Penting Perubahan Iklim: IPCC, UNFCCC dan Protokol Kyoto. (Bogor: Yayasan Pasir Luhur, 2016). UNEP. The Emissions Gap Report 2016. Executive summary. (Paris: UNEP, 2017). 
Bagaimana dengan kontribusi emisi Indonesia sendiri terhadap emisi GRK. Data menunjukkan bahwa Indonesia berada dalam deretan delapan pengemisi terbesar dunia bersama-sama dengan AS, Brasil, Cina, Uni Eropa, India, Jepang dan Meksiko. ${ }^{25}$ Data emisi Indonesia (Gambar 3) menunjukkan bahwa emisi riil Indonesia sampai tahun 2015 telah

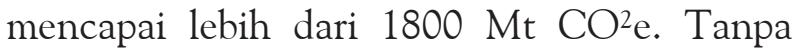

tanpa syarat, yang juga mencakup tahun-tahun sebelum tahun 2030. Sampai tahun 2030, dari skenario tanpa intervensi $(\mathrm{BaU})$ sebesar 2,881 MtCO2e, target penurunan tanpa syarat (dengan penurunan sebesar 29\% dari $\mathrm{BaU}$ ), skenario emisi dapat mencapai 2,049 $\mathrm{MtCO}^{2} \mathrm{e}$ untuk target tanpa syaratatau mencapai 1,689 $\mathrm{MtCO}^{2} \mathrm{e}$ untuk target bersyarat (dengan penurunan sebesar $41 \%$ dari $\mathrm{BaU}){ }^{26}$

\section{Gambar 3. Perkiraan Emisi Indonesia}

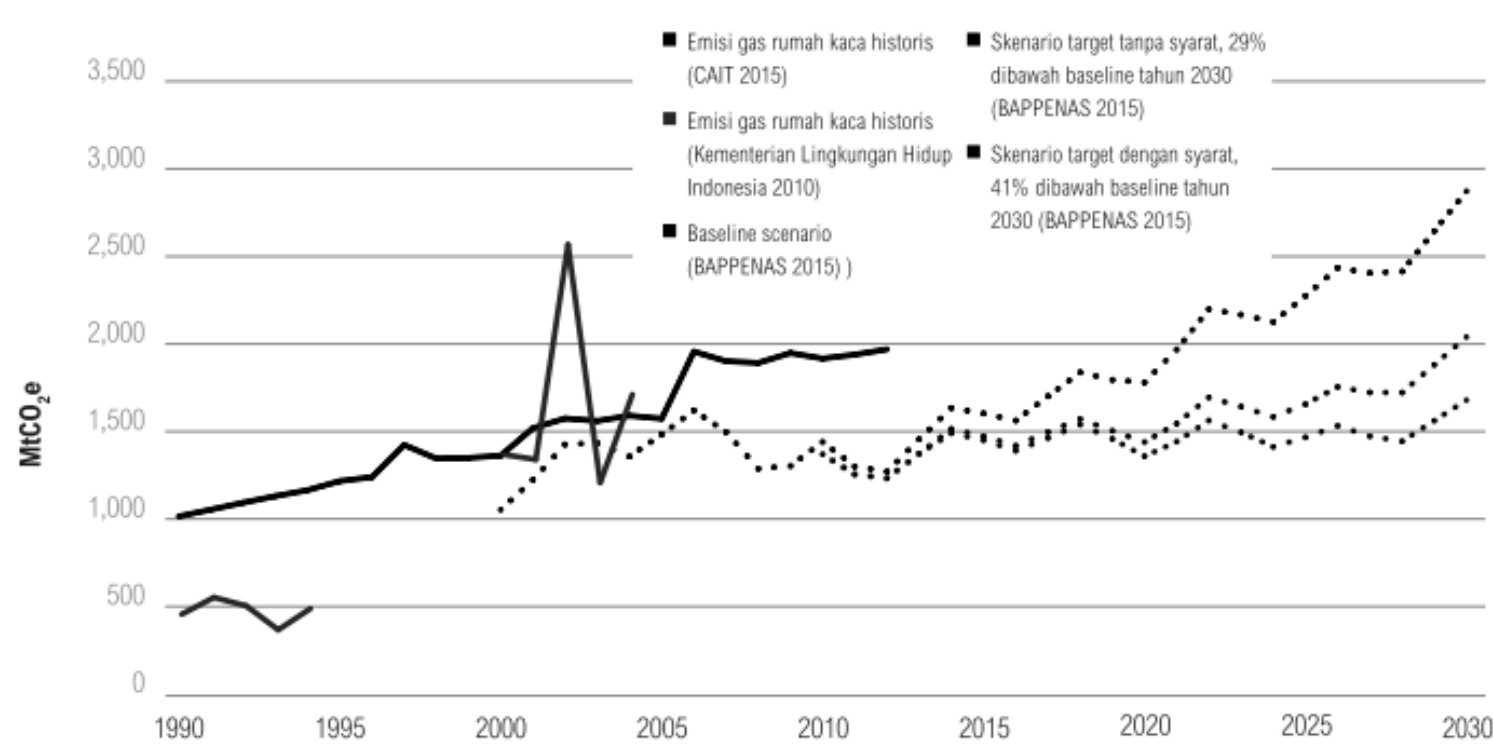

Sumber: BAPPENAS (2015); CAIT (2015); Kementerian Lingkungan Hidup Indonesia (2010).

Catatan: Sektor-sektor yang dimasukkan sebagai target Indonesia dan analisis kami meliputi samua sektor IPCC (energi; proses industri dan penggunaan komoditas; pertanian; limbah; dan penggunaan lahan, alih fungsi lahan, dan hutan). Target dan emisi historis Indonesia yang dicantumkan dalam laporan ini mencakup gas rumah kaca berikut ini: $\mathrm{CO}_{2}, \mathrm{CH}_{4}$ and $\mathrm{N}_{2} \mathrm{O}$. Total emisi Indonesia tahun 2030 akan dipengaruhi oleh perlakuan perhitungan terhadap sektor lahan, dan penggunaan mekanisme pasar internasional, jika digunakan, serta kondisi-kondisi lainnya yang tertuang di dalam INDC Indonesia. Penggunaan data historis bernilai 100 tahun GWP dari Laporan Penilaian Kedua IPCC (IPCC 1995).

Sumber: Damassa et al., 2016.

adanya intervensi, skenario emisi Indonesia yang dilaporkan melalui skema Intended Nationally Designed Committment (INDC) dapat mencapai 2,881 $\mathrm{MtCO}^{2} \mathrm{e}$ pada tahun 2030. Target penurunan tanpa syarat (dengan penurunan sebesar $29 \%$ dari $\mathrm{BaU}$ ), skenario emisi dapat mencapai 2,046 $\mathrm{MtCO}^{2} \mathrm{e}$ dan jika bersyarat dapat mencapai $1,700 \mathrm{MtCO}^{2} \mathrm{e}$ (dengan penurunan sebesar $41 \%$ dari $\mathrm{BaU}$ ). Perhitungan ini tentu diasumsikan bahwa baseline emisi Indonesia bersifat statis.

Di sisi lain, Indonesia juga telah mempublikasikan secara terpisah sebuah skenario $\mathrm{BaU}$, skenario target bersyarat dan

\footnotetext{
25 Sutamihardja dan Mulyani. Climate Change. UNEP. The
} Emissions Gap.
Hal ini menunjukkan bahwa Indonesia berperan penting dalam upaya penurunan emisi secara global. Dalam rangka memperkokoh komitmen nasional dalam rangka mitigasi dan adaptasi perubahan iklim secara global, Indonesia telah melakukan ratifikasi terhadap UNFCCC pada tahun 1994. Sepuluh tahun kemudian, Indonesia juga peserta Protokol Kyoto. Berdasarkan ketentuan Protokol Kyoto, Indonesia tidak berkewajiban dalam penurunan emisi secara global. Namun demikian, Indonesia berkepentingan dalam upaya mitigasi dan adaptasi perubahan iklim

\footnotetext{
26 T. Damassa et al. "Menginterpretasikan INDC : Menilai Transparansi Target Emisi Gas Rumah Kaca Pasca-2020.” Kertas Kerja, (2016): 1-12.
} 
karena kerentanannya terhadap dampak negatif perubahan iklim. ${ }^{27}$ Dengan demikian, komitmen politik terbaru penurunan emisi Indonesia sebagaimana tercermin dalam ratifikasi Persetujuan Paris yang ditindaklanjuti dengan NDC dan serangkaian kebijakan pembangunan berkelanjutan sekaligus menjadi taruhan secara nasional dan global.

Gambaran peristiwa kebakaran hutan dan lahan gambut pada tahun 2015 misalnya, menunjukkan besarnya tingkat emisi yang mencapai 1,1 juta ton setara karbon. Hal ini menguatkan data pemerintah bahwa dari emisi karbon sebesar 593 juta ton setara karbon per tahun dalam kurun waktu 1990-2013 bersumber dari deforestasi, degradasi hutan, dan dekomposisi area gambut. Dengan demikian, rata-rata emisi per tahun yang dihasilkan dalam kurun waktu 23 tahun tersebut jauh lebih kecil dari emisi akibat kebakaran hutan dan lahan gambut pada tahun 2015 ini saja. ${ }^{28}$

\section{Tata Kelola Isu Perubahan Iklim Global}

Secara retrospektif, upaya pengelolaan isu perubahan iklim sebagai agenda global sebenarnya bisa dirujuk pada kelahiran Deklarasi Stockholm yang merupakan hasil dari forum Konferensi PBB tentang Lingkungan Manusia tanggal 16 Juni 1972. Sebagai bagian dari isu pembangunan berkelanjutan, isu ini mulai mendapat pengakuan luas pada tahun 1980-an setelah terbentuknya Komisi Dunia PBB untuk Lingkungan dan Pembangunan (WCED) pada tahun 1987. Komisi ini menugaskan Gro Harlem Brundtland untuk menyiapkan laporan Laporan WCED yang berjudul Our Common Future. 29

Pelaksanaan Konferensi PBB untuk Lingkungan dan Pembangunan (UNCED), atau yang dikenal sebagai KTT Bumi (Rio de Janeiro

Sutamihardja dan Mulyani. Climate Change.

28 Nirarta Samadhi. "Meninjau Ulang Komitmen Emisi Indonesia", WRI, diakses 1 Mei 2017, http://www.wriindonesia.org/id/blog/meninjau-ulang-komitmen-emisiindonesia .

29 Bruntland, Go. Harlem. Report of the World Commission on Environment and Development: Our Common Future. (Oslo: WCED, 1987).
Earth Summit), 3-14 Juni 1992 memposisikan diri sebagai peletak dasar bagi terciptanya dukungan politik bagi agenda pembangunan melalui deklarasi agenda pembangunan global yang dikenal sebagai Agenda-21. Pengagendaan pembangunan berkelanjutan di mana isu perubahan iklim menjadi bagian penting di dalamnya terus mendapatkan dukungan politik lebih lanjut melalui sejumlah forum penting dan menfasilitasi bagi terbentuknya kelembagaan UNFCCC, Biodiversity Convention, dan Protokol Kyoto Kyoto.

Diakui bahwa Konferensi Perubahan Iklim pertama kali sebenarnya telah dilakukan pada tahun 1979 seiring dengan penegasan bahwa perubahan iklim menjadi masalah yang harus segera direspons. Dalam kerangka ini, Program Iklim Dunia dilansir dengan dukungan Organisasi Meteorologi Dunia (WMO), UNEP, dan International Council of Scientific Unions. Setelah melalui proses politik secara internasional, WMO dan UNEP mendirikan IPCC untuk melakukan kajian tentang dampak perubahan iklim dan bagaimana strategi penanganannya pada tahun 1988 dan dibarengi dengan proses politik selanjutnya sampai tahun 1990-an. Laporan Intergovernmental Negotiating Committee for a Framework on Climate Change (INC), kelembagaan yang dibentuk dalam proses sebelumnya, telah menjadi awal pelaksanaan Konferensi Para Pihak Ke-1 (COP1) di Berlin pada tahun 1995. Hasil penting lainnya mencakup komitmen politik peserta COP untuk menambahkan sebuah keputusan Mandat Berlin, sebuah keputusan tambahan hasil COP1 karena kesepahaman bahwa keputusan COP1 bagi negara-negara maju belum memadai. Selain itu, melalui COP1 ini juga lahir kelembagaan Ad Hoc Group on the Berlin Mandate (AGBM), SBI (Subsidiary Body for Implementation) dan SBSTA (Subsidiary Body for Scientific and Technological Advice). Proses politik lainnya adalah lahirnya Protokol Kyoto dalam forum COP3 di Kyoto, Jepang pada tahun 1997. Protokol ini menjadi tonggak sejarah disetujuinya mandat global yang mengikat negara-negara industri secara legal untuk melakukan penurunan emisi secara individual. ${ }^{30}$

\footnotetext{
30 Sutamihardja dan Mulyani. Climate Change.
} 
Momentum penguatan upaya global dalam isu perubahan iklim adalah pelaksanaan KTT Milenium pada tahun 2000 di PBB yang menghasilkan Deklarasi MDGs, yang terdiri atas 8 tujuan aksi global untuk mengatasi persoalan yang berdimensi sosial dan lingkungan. Terobosan politik lainnya dalam agenda isu perubahan iklim dan pembangunan berkelanjutan adalah lahirnya Resolusi No. 288 dalam Sidang ke-66 Majelis Umum PBB pada tahun 2012 tentang pengesahan "The Future We Want" yang dihasilkan Konferensi PBB tentang Pembangunan Berkelanjutan (UNCSD), 20-22 Juni 2012 di Rio de Janeiro, Bazil. Konferensi Rio +20 Summit ini tentu semakin memperkokoh visi dunia untuk mewujudkan agenda pembangunan berkelanjutan secara global.

Puncaknya adalah KTT Pembangunan Berkelanjutan PBB di New York pada tahun 2015 dengan deklarasi ambisiusnya: Transforming Our World: 2030 Agenda for Sustainable Development, kemudian diadopsi melalui Resolusi MUPBB No. 70/1 tertanggal 25 September 2015 dan dikenal sebagai agenda Tujuan Pembangunan Berkelanjutan, mencakup 17 tujuan dan 169 target. Persetujuan 195 negara untuk menyampaikan rencana lima tahunan pengurangan GRK dalam Konvensi Perubahan Iklim Dunia ke-21 di Paris pada tahun dan pengesahan PA, serta komitmen penurunan emisi setiap negara yang lebih mengikat dalam skema NDC dalam Konvensi Perubahan Iklim Dunia ke-22 di Maroko, pada tahun 2016 dapat merefleksikan sebuah konstelasi sistem politik internasional yang kondusif dalam pengelolaan isu perubahan iklim.

Namun demikian, sejumlah kebijakan AS yang menarik diri dari sejumlah kesepakatan internasional dan secara khusus rencana penarikan terhadap PA, menunjukkan rapuhnya kondusifitas sistem dunia bagi pengelolaan isu ini. Rapuhnya kondusifitas ini didasari bahwa AS masih memiliki peran politik dan ekonomi yang penting secara global sehingga kebijakannya dapat berpotensi merubah konstelasi dukungan setiap negara dalam isu pengelolaan perubahan iklim global. Konstelasi tata kelola perubahan iklim global seperti ini cenderung mengarah pada satu atau dua skenario sistem dunia Kappen.

\section{Skenario Sistem Dunia Networks dan Fragmentation}

Merujuk pada konstelasi tata kelola perubahan iklim global selama ini dan kecenderungan kebijakan yang diambil negaranegara tertentu khususnya AS terlihat lebih mendekati skenario sistem dunia networks dan fragmentation. Terlihat mendekati dengan skenario sistem dunia Networks (multilateralisme polisentris) karena dicirikan dengan potensi kuatnya kerja sama antar-negara atau dengan aktor-aktor non-negara. Potensi kuatnya kerja sama ini karena dalam kerangka sistem ini, sistem multilateral tidak didominasi oleh kekuatan-kekuatan pengkutuban (tidak adanya kekuatan-kekuatan dominan dalam sistem internasional secara absolut), kuatnya aktor-aktor sipil global dan berlakunya sistem ekonomi pasar secara global.

Era sekarang ini dalam batas tertentu mencerminkan skenario ini. ${ }^{31}$ Skenario ini juga sekaligus menguatkan pola tata kelola isu-isu global yang semakin partisipatoris dan semakin kuatnya peran aktor non-negara dan kekuatan sipil secara global khususnya entitas bisnis seperti perusahaan multinasional. ${ }^{32}$ Selain itu, hal yang mencirikan skenario ini bahwa sifat kerja samanya biasanya kerja sama fungsional.

Skenario seperti ini sebenarnya berakar dari tidak adanya seorang 'hegemon' dalam politik internasional dalam artian absolut yang dimulai sejak tahun 1990-an ketika berakhirnya era Perang Dingin dan tata dunia tidak lagi dikuasai oleh AS secara hegemonik. ${ }^{33}$ Dalam perspektif ini, sistem dunia 'akan kehilangan' kekuatan-kekuatan hegemonik untuk stabilitas internasional. Dalam situasi seperti ini, sistem dunia tentu akan mengalami sejumlah masalah

\footnotetext{
Weiss, "Governance, Good Governance...".

Weiss, "Governance, Good Governance...".

Tsuneo Akaha and Frank and Langdon, (ed.). Japan in the Posthegemonic World. (Boulder and London: Lynne Rienner Publisher, 1993).
} 
seperti menurunnya rezim internasional. ${ }^{34}$ Penarikan AS dari kesepakatan PA misalnya, akan berpotensi menarik dukungan sejumlah negara lain yang telah meratifikasi PA karena kuatnya pengaruh power politics AS.

Meskipun demikian, perubahan hegemonik dalam sistem dunia, bagaimana pun, sebagai hal lumrah karena sistem politik global itu bersifat siklis, berjalan dari arah kondisi ekuilibrium ke kondisi disekuilibrium, serta pada akhirnya mengarah pada sebuah resolusi dan kemudian kembali pada kondisi ekuilibrium. ${ }^{35}$ Ekuilibrium di sini tidak identik dengan keseimbangan karena sebuah sistem dipandang bersifat ekuilibrum (stabil) sepanjang setiap negara memandang bahwa konstelasi tersebut pada posisi paling menguntungkan bagi dirinya.

Terlepas dari perdebatan turunnya peran penting AS dalam masalah iklim global, fenomena yang mulai terlihat dalam pemerintahan AS dewasa ini, implikasi terpenting dalam skenario ini adalah sulitnya pencapaian konsesus. Hal ini karena kebijakan dan perilaku negara-negara yang secara tradisional sebagai 'hegemon' atau pemegang pengaruh dalam konstelasi politik global tidak lagi mencerminkan sebagai seorang 'hegemon' untuk mengatasi 'barang publik' global bersama. Sejarah menunjukkan bahwa sikap dan kebijakan AS semakin tidak konsisten sifat hegemoniknya dengan perjalanan negosiasi hukum laut, penentangan kesepakatan KTT Bumi pada tahun 1992 sampai penolakannya untuk meratifikasi Protokol Kyoto sampai berakhirnya rezim ini. ${ }^{36}$

Dalam konteks inilah, seiring dengan turunnya peran negara secara tradisional dan semakin terbukanya peran aktor-aktor sipil non-negara secara global dalam proses global governance, potensi instabilitas konstelasi sistem dunia pun tidak terhindarkan. Dengan demikian, tuntutan global governance dalam isu-isu global tidak terkecuali isu perubahan

\footnotetext{
34 Jurg Maartin Gabriel. Worldviews and Theories of International Relations. (New York: ST. Martin's Press, Inc., 1994).

35 Gabriel. Worldviews and Theories

36 Akaha and Langdon, Japan in the Posthegemonic World.
}

iklim yang semakin adil, partisipatoris dan non-ideologis akan semakin menjadi pilihan yang paling rasional setiap negara. Dalam batas tertentu, politisasi isu-isu ketidakadilan sosial dan ekonomi dalam isu perubahan iklim, global biasanya juga akan semakin kuat. Kritik Stiglitz terhadap dampak negatif globalisasi misalnya, untuk sebagian merefleksikan hal ini. ${ }^{37}$

Skenario sistem dunia Networks mendorong munculnya konsepsi tata kelola global. Konsepsi ini dicirikan dengan tidak adanya otoritas tunggal seperti halnya dalam konteks nasional. ${ }^{38}$ Konsepsi ini dapat diartikan sebagai sekumpulan cara beragam yang dipakai setiap individu atau lembaga, baik publik maupun swasta, untuk mengatasi masalah bersama secara global. Mereka mendefinisikan tata kelola ini sebagai sekumpulan hukum, normanorma, kebijakan dan kelembagaan yang mendefinisikan, menciptakan dan menengahi hubungan antar-warga negara, masyarakat, pasar dan negara---panggung kekuasaan dan objek dari pelaksanaan kekuasaan publik. Konsep governance itu sendiri secara tradisional sering diasosikan dengan konsepsi governing, yakni merujuk pada lembaga, otoritas politik dan kontrol.

Namun demikian, James Rosenau ${ }^{39}$ misalnya, merujuk konsepsi governance sebagai hal yang lebih formal misalnya, aturan-aturan (hukum, norma, kode perilaku) dan praktek atau lembaga yang diciptakan untuk mengatur tindakan kolektif yang melibatkan banyak aktor (otoritas negara, organisasi internasional, organisasi sipil dan entitas sektor swasta). Melalui mekanisme dan pengaturan seperti ini, kepentingan kolektif diartikulasikan, hakhak dan kewajiban ditegakkan, dan konflik ditengahi. Munculnya "ketimpangan tata kelola" berakar pada persoalan bagaimana setiap aktor dan kekuatan-kekuatan ekonomi, dan masyarakat mampu mengelola dampak yang tidak diinginkan. Dalam konteks ini, "ketimpangan tata kelola" memberikan ruang

\footnotetext{
37 Stiglitz, Globalization.

Weiss and Thakur, Global Governance.

Weiss and Thakur, Global Governance.
} 
bagi terjadinya perilaku menyimpang semua pihak. Thomas Kuhn menyebutnya sebagai pockets of apparent disorder. ${ }^{40}$

Proses governance ini berlangsung secara berkesinambungan melalui mana konflik dan serangkaian perbedaan diakomodasi dan aksiaksi kerja sama dilakukan. Secara kelembagaan, proses ini melibatkan lembaga-lembaga formal dan rezim untuk menegakkan kesepakatan serta kesepakatan-kesepakatan informal bagi setiap orang atau lembaga yang telah menyetujui atau mempersepsikannya sebagai kepentingannya. Secara politis, tata kelola global ini identik dengan hubungan antar-pemerintah meskipun sekarang konsep ini juga melibatkan organisasi non-pemerintah, gerakan masyarakat, perusahaan multinasional dan pasar modal global, dan media massa. ${ }^{41}$ Dengan kata lain, skenario Networks ini agak mirip dengan cara pandang polisentrisme dalam pengelolaan isu global bersama. Dengan cara pandang ini, melalui kerja sama internasional, tata kelola global diasumsikan akan mampu menjadi mekanisme yang efektif bagi setiap aktor yang terlibat di dalamnya. Situasi ini pada akhirnya akan mendorong terjadinya proses pendalaman, perluasan dan penguatan keterhubungan secara transnasional baik formal maupun non-formal dalam dimensi sosial dan politik global. ${ }^{42}$

Pengaruh politik AS diakui telah menurun secara global. Meskipun demikian, perannya dalam tata politik global masih tetap signifikan. Dalam konteks pengelolaan perubahan iklim menunjukkan bahwa peran AS pun masih signifikan. Sebagai contoh, meskipun pembiayaan pemerintah untuk riset dan pengembangan energi bersih paling kecil dibandingkan dengan pembiayaan untuk riset dan pengembangan sektor lainnya, AS tetap menjadi penyedia dana pemerintah terbesar bagi kegiatan ini secara global. ${ }^{43}$ Kasus yang sama, kerja sama internasional untuk melipatgandakan dana pemerintah untuk

\footnotetext{
40 Weiss and Thakur, Global Governance.

41 Weiss and Thakur, Global Governance.Weiss, "Governance, Good Governance...".

42 Weiss, "Governance, Good Governance...".

43 Sivaram and Norris."The Clean Energy Revolution".
}

tujuan riset tersebut. Tanpa peran aktif AS, peta jalan pengumpulan dana pemerintah sebesar $\$ 20$ miliar per tahun sampai 2020 bakal menghadapi tantangan besar. ${ }^{44}$ Situasi seperti ini menyiratkan tetap pentingnya telaah realpolitics dalamsetiap proses tata kelola global di tengah-tengah beragamnya aktor yang terlibat di dalamnya. Artinya, dalam politik praktis, proses tata kelola tersebut tetap membutuhkan dukungan penuh dari aktor-aktor yang memiliki posisi kuat secara struktural dalam arena politik dan ekonomi global. ${ }^{45}$

Seberapa besar proses tata kelola global dapat berdampak imperatif pada pengambil keputusan baik di dalam negeri AS maupun di negara-negara lain, akan sangat terkait dengan isu legitimasi dari kerja sama itu sendiri. ${ }^{46} \mathrm{Hal}$ ini berarti bahwa isu legitimasi juga berperan menentukan terhadap keberhasilan tata kelola global. Oleh karena itu, per definisi penegakkan kerja sama pengelolaan perubahan iklim global dalam skenario Networks tidak dapat dilakukan sama seperti halnya dalam perjanjian internasional yang mengikat secara politik dan hukum atau layaknya kebijakan domestik suatu negara. Untuk mencapai itu, tentu menyaratkan adanya legitimasi. Legitimasi dapat diraih baik secara global maupun domestik. Secara global, legitimasi dapat dilihat apakah sejauh ini telah ada perjanjian internasional yang mengikat secara politik dan hukum (hard law). Isu legitimasi secara domestik, dapat diartikan sebagai dukungan rakyat terhadap pemerintahnya atas kebijakan yang diambilnya.

Dengan melihat cara pandang skenario sistem dunia yang sifatnya Networks ini, agenda perubahan iklim akan menjadi isu yang akan selalu mengalami tarik-menarik

44 Sivaram and Norris."The Clean Energy Revolution”.

45 Weiss, Governance, Good Governance. Robert Repetto. America's Climate Problem, the Way Forward, Earthscan. diakses kembali 19 Juni 2017, http://www.earthscan. co.uk/tabid/102581/Default.aspx\#dnn_ctr287409 ViewProductInfo fragment3;

46 S. Bernstein and Cashore, B. Nonstate Global Governance: Is Forest Certification a Legitimate Alternative to a Global Forest Convention? inHard Choices, Soft Law: Voluntary Standards In Global Trade, Environment And Social Governance (2003), 33-64. 
kepentingan yang kuat antar-negara karena tidak kuatnya kekuatan-kuatan utama dunia dan kedudukan kesepakatan yang diambil tidak lagi sebagai hardlaw dalam pengertian mutlak. PA diyakini menjadi satu instrumen yang untuk pertama kalinya dapat menyatukan upaya ambisius semua negara dalam mitigasi iklim dunia. Meskipun demikian, persetujuan yang berkedudukan sebagai hardlaw ini masih harus dibuktikan komitmen setiap negara peratifikasi. Indikasi perubahan kebijakan AS di bawah Pemerintahan Presiden Donald Trump yang mengindikasikan adanya perubahan kebijakan lingkungan di AS secara mendasar bagaimana pun akan berpotensi membawa efek tular terhadap kekuatan-kekuatan besar lainnya.

Konstelasi tata kelola perubahan iklim global selama ini dan kecenderungan kebijakan yang diambil negara-negara tertentu khususnya AS juga terlihat cocok dengan skenario sistem dunia fragmentation. Dalam skenario ini, sistem dunia lebih merefleksikan sebuah konstelasi politik internasional yang kurang kondusif, kuatnya potensi anarkhisme politik, sosial ekonomi dalam skala global. Selain itu, ciri yang lain mencakup kuatnya politik identitas. Karena sifat sistem ini tidak mendorong adanya trust, pada akhirnya kerja sama pun sulit dilakukan. Situasi seperti ini tentu diakibatkan oleh lemahnya peran negara sehingga berpotensi pada terciptanya situasi keos (chaotic).

Sejumlah faktor turut mendorong terjadinya skenario ini misalnya, persoalan ketimpangan akses lapangan kerja, keterbatasan sumber daya, menguatnya fundamentalisme dan irasionalisme, melemahnya sistem negarabangsa dan lembaga-lembaga dunia, perubahan kekuatan dunia secara horisontal dan vertikal, serta terjadinya proliferasi senjata pemusnah massal.

Dalam kondisi skenario dunia yang penuh ketidakpastian seperti ini, pengelolaan isu perubahan iklim global akan semakin penuh dengan ketidakpastian. Sebagaimana ditegaskan di atas, PA menjadi sebuah kesepakatan baru yang berbeda dengan persetujuan iklim sebelumnya. Namun demikian, dalam kondisi ketidakpastian konstelasi sistem dunia, skenario ini akan menempatkan isu perubahan iklim termasuk di dalamnya eksistensi rezim perubahan iklim global itu sendiri pun akan mengalami tekanan yang sama secara politik.

\section{Respons Indonesia}

Menyikapi konstelasi sistem dunia tersebut, Indonesia perlu mengambil pola kebijakan sebagai berikut. Dalam rangka menyikapi skenario sistem dunia networks dan fragmentation, Indonesia perlu terus memperkokoh politik iklim nasional dalam bingkai paradigma hak membangun (rights to development). Hal ini berarti bahwa Indonesia perlu mengelola isu perubahan iklim dan agenda pembangunan berkelanjutan berdasarkan kondisi nasional. Sementara itu, secara internasional, sama seperti dalam skenario multilateral, upaya diplomasi iklim perlu terus diarahkan dalam rangka memperkokoh kredibilitas rezim perubahan iklim global supaya lebih bersifat partisipatoris dan adil. Dalam kerangka ini, Indonesia juga perlu mendorong dunia internasional bahwa dalam isu bagi beban dalam pengelolaan isu perubahan iklim bagi semua negara harus dilaksanakan berdasarkan prinsip common but differentiated responsibilities. Dengan demikian, negara-negara berkembang memiliki daya tawar dalam menekan komitmen dukungan negara-negara industri dalam pengelolaan perubahan iklim secara nasional. Upaya ini juga dapat memperkuat kemitraan dan kerja sama global dalam isu perubahan iklim dan sekaligus mengurangi kritik kentalnya muatan ideologi dalam setiap upaya kemitraan dan kerja sama global. ${ }^{47}$ Selain itu, dalam skenario sistem dunia ini, upaya penguatan kemitraan dengan aktoraktor sipil global untuk ikut menekan negaranegara industri memenuhi komitmen mereka dalam membantu negara-negara berkembang dalam pengelolaan isu perubahan iklim global pun perlu disasar.

Sikap internasional Indonesia untuk mendorong negara-negara lain khususnya negara-

Stiglitz, Globalization. Weiss, "Governance, Good Governance...”. 
negara maju dalam mengimplementasikan pascapengumuman mundurnya AS dari persetujuan tersebut misalnya, dapat mencerminkan hal ini. Seperti kita ketahui bahwa sebagai salah satu pengemisi terbesar dunia, penarikan diri AS tersebut akan berdampak pada semakin beratnya realisasi target penurunan emisi global, dan potensi merosotnya pendanaan untuk negosiasi iklim global dan dukungan terhadap negaranegara berkembang. ${ }^{48}$

Persoalan pencapaian target penurunan temperatur misalnya, dapat didukung dengan sejumlah argumen berikut ini. Pada 2014, kontribusi emisi AS telah mencapai 14\% dari tingkat emisi global atau senilai 6,87 juta ton setara karbon. Melalui skema NDC, AS berkomitmen untuk menurunkan senilai 2628\% di bawah tingkat emisi pada tahun 2005. Studi Sanderson dan Knutti yang diterbitkan di Jurnal Nature Climate Change, edisi Desember 2016 menegaskan bahwa keterlambatan pencapaian target mitigasi di AS akan berakibat pada sulitnya pencapaian target $2^{\circ} \mathrm{C}$. Hal yang sama ditegaskan ilmuan Massachusetts Institue of Technology (MIT) bahwa tanpa peran AS, temperatur global akan lebih tinggi $0.3^{\circ} \mathrm{C}$ pada akhir abad ini sekalipun semua komitmen peratifikasi PA tercapai. ${ }^{49}$

Persoalan lain terkait dengan isu pendanaan. Pada tahun 2016, kontribusi pendanaan iklim global AS mencapai 6,44 juta dolar AS per tahun atau setara dengan 20\% dari pembiayaan operasional UNFCCC. Akibatnya, kegiatan UNFCCC, termasuk di dalamnya proses negosiasi yang sedang berjalan terkait modalitas operasional PA kemungkinan dapat terganggu. Persoalan penting lainnya adalah potensi terganggunya kelancaran pendanaan iklim untuk mendukung upaya adaptasi dan mitigasi perubahan iklim di negara-negara berkembang. Pemerintah AS di bahwa Presiden Barrack

48 Fabby Tumiwa. "Implikasi Keluarnya Amerika Serikat dari Paris Agreement terhadap Agenda Perubahan Iklim Global", diakses 22 November 2017, http://iesr. or.id/2017/06/implikasi-keluarnya-amerika-serikat-dariparis-agreement-terhadap-agenda-perubahan-iklimglobal-bagian-2/?lang=en.

49 Tumiwa, "Implikasi Keluarnya Amerika Serikat".
Obama telah berkomitmen untuk mendukung pendanaan Dana Iklim Global (Global Climate Fund) mencapai 30\% dari total dana yang dibutuhkan atau sebesar 3 miliar dolar AS. Tantangan lain juga mencakup dievaluasinya sejumlah skema pendanaan iklim yang telah dikucurkan AS selama ini. ${ }^{50}$

Dalamkondisisepertiini, upaya peningkatan solidaritas global untuk mempertegas komitmen global dalam masalah iklim menjadi hal penting. Dalam skenario sistem dunia networks dan fragmentation ini, Indonesia dengan kedudukannya sebagai negara yang memiliki kemauan politik kuat dalam isu perubahan iklim secara global dapat memainkan perannya sebagai jangkar dalam mendorong solidaritas global dalam implementasi PA. Kebijakan Indonesia untuk tetap konsisten terhadap pelaksanaan PA di depan para pemimpin negara-negara Uni Eropa pada bulan Juni 2017 menunjukkan kuatnya kemauan politik tersebut. ${ }^{51}$ Inisiasi pembentukan sebuah aliansi baru dengan sejumlah negara yang memiliki kemauan politik yang sama dalam isu ini seperti Tiongkok, India, Brasil, Meksiko dan Afrika Selatan misalnya, pun dapat dapat dipertimbangkan. ${ }^{52}$

Untuk menjalan peran ini Indonesia juga perlu memperkuat kemauan politiknya dalam merealisasikan serangkaian kebijakan mitigasi perubahan iklim secara nasional. Secara normatif, upaya ini mudah dilakukan. Namun demikian, tanpa pengawalan ketat dalam implementasinya, pemenuhan komitmen ini akan sulit dilakukan. Kebijakan moratorium konsesi hutan misalnya, dinilai hanya dapat mengurangi alih fungsi hutan dan lahan bukan untuk menghentikan deforestasi. Kasus yang lain masih rendahnya target penurunan emisi dari sektor energi. Dalam konteks ini, untuk membantu merealisasikan komitmen tersebut,

\footnotetext{
50 Tumiwa, "Implikasi Keluarnya Amerika Serikat”.

51 Republika Online. "JK Tegaskan Komitmen Indonesia Dukung Kesepakatan Paris”, diakses 21 November 2017, http://nasional.republika.co.id/berita/nasional/ umum/17/06/15/orkxly-jk-tegaskan-komitmenindonesia-dukung-kesepakatan-paris.

52 Tumiwa, "Implikasi Keluarnya Amerika Serikat”.
} 
penguatan pengembangan energi terbarukan menjadi penting dilakukan. Untuk mencapai ini, kemauan politik untuk menyediakan kebutuhan pendanaan senilai kira-kira 9,4 miliar dolar AS sampai 2030 untuk mencapai target pembangunan pembangkit energi dengan kapasitas 45 GW bersumber energi terbarukan menjadi tantangan berat pemerintah. ${ }^{53}$

Arti penting pemenuhan komitmen ini tentu diarahkan sebagai jangkar untuk mendorong komitmen yang sama negara-negara industri khususnya negara-negara peratifikasi PA. Untuk memperkuat upaya ini, diplomasi yang mengedepankan aspek constructive engagement yang sifatnya multitracks terhadap kekuatan-kekuatan utama dunia juga terus dilakukan secara konsisten untuk mendorong sebuah konsensus global yang mengikat secara politik dan hukum terhadap implementasi perjanjian iklim global, agenda SDGs, dan komitmen dukungan mereka terhadap negaranegara berkembang.

Respons kebijakan Indonesia dalam dua skenario sistem dunia ini memang tidak dapat menggambarkan kondisi yang ideal. Tingginya kompleksitas isu perubahan iklim global dan adanya kendala yang bersifat kognitif, respons kebijakan setiap negara biasanya merepresentasikan model respons kebijakan yang bersifat satisficying atau inkremental..$^{54}$

\section{PENUTUP}

Konstelasi politik nasional dan internasional sangat mudah berubah pada arah yang semakin sulit diprediksikan sehingga isuisu yang berdimensi global akan menghadapkan setiap negara dalam posisi sulit. Hal ini juga sekaligus merefleksikan kuatnya tarik-menarik kepentingan antara negara-negara maju dan negara-negara berkembang.

53 Grace Tjandra. "The Paris Agreement: Can Indonesia Be The Next Brazil?", diakses 22 November 2017, https:/ thediplomat.com/2017/09/the-paris-agreement-canindonesia-be-the-next-brazil/.

$54 \quad$ John Forrester, "'Bounded Rationality and the Politics of Muddling Through”, Public Administration Review 44 (1984): 23-30.
Menempatkan isu pengelolaan perubahan iklim global dalam kerangka sistem dunia secara kekinian dapat diteropong dengan skenario sistem dunia yang akan terjadi sehingga setiap negara dapat meresponsnya secara tepat. Dalam kerangka ini, skenario sistem dunia van Kappen dapat menjadi salah satu instrumen analisisnya. Konstelasi tata kelola perubahan iklim global selama ini dan kecenderungan kebijakan yang diambil negara-negara tertentu khususnya AS terlihat lebih mendekati skenario sistem dunia networks dan fragmentation.

Dengan mendasarkan pada skenario sistem dunia Kappen, pengelolaan isu perubahan iklim secara global dan bagaimana Indonesia harus menyikapinya gambil sikap dan kebijakan secara nasional dan global menunjukkan ruang manuver yang terbatas. Keterbatasan ruang manuver ini tentu terkait dengan kecilnya peluang terjadinya skenario normatif sistem dunia. Hal ini bisa dipahami karena semakin besarnya tantangan tidak dari jenis ancaman, faktor-faktor pendorong dan juga semakin kuatnya keterlibatan aktor-aktor non-negara. Hal lain, semakin merosotnya sistem negarabangsa sebagai sebuah entitas politik dan legal dalam pengelolaan isu-isu global bersama juga menambah persoalan ini.

Dalam kondisi demikian, setiap negara harus mengambil kebijakan yang sifatnya satisfycing. Persoalan perubahan iklim telah menjadi persoalan luar biasa dan karena itu diperlukan aksi-aksi nasional dan global yang tegas dan mengikat berdasarkan prinsip common but differentiated responsibility, keadilan iklim dan prinsip hak membangun. Indonesia tentu perlu memperkuat kemauan politiknya dalam mewujudkan serangkaian kebijakan mitigasi sebagai jangkar untuk mendorong komitmen negara-negara maju dalam isu perubahan iklim. Untuk menuju ke sana, diplomasi constructive engagement yang bersifat multitracks terhadap kekuatan-kekuatan utama dunia perlu terus dilakukan untuk mendorong sebuah konsensus global yang mengikat secara politik dan hukum. 


\section{DAFTAR PUSTAKA}

\section{Buku}

Akaha, Tsuneo and Frank and Langdon, (ed.). Japan in the Posthegemonic World. Boulder and London: Lynne Rienner Publisher, 1993.

Bernstein, S., \& Cashore, B. "Nonstate Global Governance: Is Forest Certification a Legitimate Alternative to a Global Forest Convention?" in Hard Choices, Soft Law: Voluntary Standards In Global Trade, Environment And Social Governance, 2003.

Brundtland, Gro Harlem. Report of the World Commission on Environment and Development: Our Common Future. New York: WCED, 1987.

Edenhofer, O., R. Pichs-Madruga, Y. Sokona, E. Farahani, S. Kadner, K. Seyboth, A. Adler, I. Baum, S. Brunner, P. Eickemeier, B. Kriemann, J. Savolainen, S. Schlömer, C. von Stechow, T. Zwickel and J. C. Minx, eds.. Climate Change 2014: Mitigation of Climate Change. Contribution of Working Group III to the Fifth Assessment Report of the Intergovernmental Panel on Climate Change. Cambridge University Press, Cambridge, UK and NY, USA, 2014. Gabriel, Jurg Maartin. Worldviews and Theories of International Relations. New York: ST. Martin's Press, Inc., 1994.

Howlett, Michael and M. Ramesh. Studying Pubic Policy: Policy Cycle and Policy Subsystems, NY: Oxford Univ. Press, 1995.

Jackson, Robert \& Sorensen, George. Pengantar Studi Hubungan Internasional, terj. Yogyakarta: Pustaka Pelajar, 2005.

Kumar, Ashwani and Dirk Messner, eds. Power Shifts and Global Governance, Challenges from South and North, London: Routledge, 2011.
Light, Donald; Keller, Suzanne and Calhoun, Craig. Sociology. Fifth ed. New York: Alfred A . Knopf, Inc., 1989.

Morgenthau, Hans J. Politik Antar-Bangsa (terj.). Direvisi Kenneth W Thompson. Jakarta: Yayasan Pustaka Obor Indonesia, 2010.

Little, Richard. The Balance of Power in International Relations: Metaphors, Myths and Models. UK: Cambridge Univ. Press, 2007.

Ross, Katherine., Damassa, Thomas. Assessing the Post-2020 Clean Energy Landscape. Technical Note. USA: World Resource Institue, 2015.

Rourke, John T. International Politics on the World Stage. California: Brooks/Cole Publishing Co., 1986.

Stiglitz, Joseph E. Globalization and Its Discontents. New York: Norton, 2002.

United Nations Environmental Programme (UNEP). The Emissions Gap Report 2016. Executive summary. Paris: UNEP, 2017.

Weiss, Thomas G. and Ramesh Thakur. Global Governance and the UN, an Unfinished Journey, Bloomington and Indianapolis: Indiana Univ. Press, 2010.

Weiss, Thomas G. "Governance, Good Governance and Global Governance: Conceptual and Actual Challenges", dalam Ashwani Kumar dan Dirk Messner (ed.), Power Shifts and Global Governance, Challenges from South and North, UK \& USA, Anthem Press, 2011.

\section{Jurnal}

Forrester, John. "Bounded Rationality and the Politics of Muddling Through," Public Administration Review 44 (1984): 23-30.

Galtung, Johan. "A Structural Theory of Imperalism. Journal of Peace Research," Vo. 8, No. 2, (1971): 81-117. 
Sivaram, Varun and Teryn Norris. "The Clean Energy Revolution: Fighting Climate Change With Innovation," Foreign Affairs, Vol. 95, Issue 3, (June 2016): 147-156.

\section{Makalah dan Kertas Kerja}

Damassa, T., Fransen, T., Haya, B., Ge, M., Pjeczka, K., Ross, D. A. N. K., \& Eksekutif, R. "Menginterpretasikan Indc: Menilai Transparansi Target Emisi Gas Rumah Kaca Pasca-2020.” Kertas Kerja., 2016: $1-12$.

Inter-Governmental Panel on Climate Change/ IPCC. "Climate Change 2007: Mitigation of Climate Change. Contribution of Working Group III to the Fourth Assessment report of the IPCC." Summary for Policy Makers and Technical Summary, 2007.

Kappen, Frank van. New security threats; The UN, NATO and Challenges in global governance. Clingendael Lecture (Indonesia), tt.

\section{Internet}

Repetto, Robert. "America's Climate Problem, the Way Forward", Earthscan, diakses kembali 19 Juni 2017, http://www. earthscan.co.uk/tabid/102581/Default. aspx\#dnn_ctr287409_ViewProductInfo_ fragment3;.
Republika Online. "JK Tegaskan Komitmen Indonesia Dukung Kesepakatan Paris", diakses 21 November 2017, http:// nasional.republika.co.id/berita/nasional/ umum/17/06/15/orkxly-jk-tegaskankomitmen-indonesia-dukung-kesepakatanparis.

Samadhi, Nirarta. "Meninjau Ulang Komitmen Emisi Indonesia", WRI, diakses 1 Mei 2017, http://www.wri-indonesia.org/id/ blog/meninjau-ulang-komitmen-emisiindonesia.

Tumiwa, Fabby. "Implikasi Keluarnya Amerika Serikat dari Paris Agreement terhadap Agenda Perubahan Iklim Global", diakses 22 November 2017, http:// iesr.or.id/2017/06/implikasi-keluarnyaamerika-serikat-dari-paris-agreementterhadap-agenda-perubahan-iklim-globalbagian-2/?lang $=$ en.

Tjandra, Grace. "The Paris Agreement: Can Indonesia Be The Next Brazil?", diakses 22 November 2017, https://thediplomat. com/2017/09/the-paris-agreement-canindonesia-be-the-next-brazil/. 